\title{
Environmental, energy and economic security: Assessment and interaction
}

\author{
Yaryna Samusevych ${ }^{1 *}$, Alina Vysochyna $^{1}$, Tetiana Vasylieva $^{2}$, Serhiy Lyeonov ${ }^{3}$, and Svitlana Pokhylko $^{4}$ \\ ${ }^{1}$ Sumy State University, Department of Accounting and Taxation, 40007 Sumy, Ukraine \\ ${ }^{2}$ Sumy State University, Oleg Balatskyi Academic and Research Institute of Finance, Economics and Management, 40007 Sumy, \\ Ukraine \\ ${ }^{3}$ Sumy State University, Department of Economic Cybernetic, 40007 Sumy, Ukraine \\ ${ }^{4}$ Sumy State University, Department of Finance and Entrepreneurship, 40007 Sumy, Ukraine
}

\begin{abstract}
The paper is devoted to the investigation of environmental, energy and economic security by multivariate analysis methods. A set of indicators selected for research conducting includes 9 parameters for each security type. Study sample is formed by data for 6 Eastern European countries (Ukraine, Moldova, Poland, Romania, Hungary and Slovak Republic) for the period 2000-2019. Empirical study was conducted by factor analysis, which allowed identifying the main components of environmental, energy and economic security. Comparison of the results obtained for the studied countries showed differentiation of individual profiles of such types of security. Investigation of integral vectors of environmental, energy and economic security showed the highest level of interaction between energy and environmental security and the lowest one between energy and economic security.
\end{abstract}

\section{Introduction}

Expansion of the concept of sustainability opened the prospect for improvement institutional and technological framework of national economy functioning. Nowadays environmental performance creates a background for the country's competitiveness in conditions of effective environmental regulation [1-3] that leads to the transformation of the national economy system [4]. New concept of country's policy leads to the appearance of the new instruments in the financial system, which are able to provide financial support for sustainability of economy [5].

Concept of sustainable development became crucial not only at the macro level but also for corporate management $[6,7]$. Ability to generate environmental innovation is one of the criteria of company's competitiveness $[8,9]$. Its importance for a moment has pretty the same impact on the enterprises development as other economic factors [10-12]. Implementation of sustainability reporting and audit becomes an important condition of firms' image and reputation [13-15]. Its expansion on the country level forms a background for macroeconomic stability through national brand development [16].

Traditionally economic growth is associated with increase of energy use and environmental pollution [17]. Competitiveness issues in globalization conditions require involvement additional sources to enhance country's position [18, 19]. Even shifting to the technological development is not enough for minimizing a hazardous impact of economic growth on the society and environment [20-22]. Electricity consumption remains a key driver of economic development. On the other hand, implementation the concept of sustainable development led to the increase of renewables in energy production structure. Some researches revealed that renewable energy growth is one of the determinants of macroeconomic competitiveness and stability [23-25]. In addition, existing empirical findings [26] confirmed country's possibility to provide economic growth and to remain financial and social stability simultaneously. Thus the concept of sustainable development has led to an increase of the attention to the country's environmental, economic and energy security.

\section{Literature Review}

National security is a strategic issue in the country's development, which is of particular relevance in the context of globalization. Traditionally economic and financial security questions are considered through regulation effectiveness. Ensuring national security in the context of sustainable development requires a transition from isolated regulation of each direction to formulation of a comprehensive strategy. It is proved that taking into account the interaction between different factors of national development provides increase of efficiency of public management [27-28]. In this context, it is important to find national security components that demonstrate the closest possible relationship.

On the regional level interaction of economic and ecological development may be evaluated through the

* Corresponding author: y.samusevych@uabs.sumdu.edu.ua 
volume of environmental pollution and efforts aimed to their reduction [29, 30]. However, another group of researches revealed that core precondition of socioecological-economic balance of territory is effective financial source implementation [31, 32]. Increase in financial potential creates a background for economic growth [33], but only country's orientation for sustainability forms a potential for environmentallyfriendly economic development [34]. In this context should highlight, that social impact, especially the influence of worlds' society becomes a powerful instrument of changing country's economic policy taking into account environmental issues [35-38]. This provides an opportunity for integral estimation of economic and environmental security [39, 40].

Environmental component becomes core trigger in ensuring different types of countries' national security. Thus, environmental factors improvement determinates the growth of food security [41-43]. Besides, green investments expansion creates a potential for new form of environmental and economic security interaction. So, increase in green investments not only leads to the development of renewable energy and reducing in environmental pollution, but also determinates a GDP growth [44].

Environmental and economic factors might be considered as energy security precondition in terms of energy production and distribution [45]. Enhancing of social component of sustainable development is also considered with a trial nature of environmental, economic and energy factors interaction [46, 47]. At the same time, integrated estimates of socio-economic interaction are widespread today [48].

Attention should also be paid to the indicators used to assess different types of security. It can be a resource approach [49], process approach [50], risk assessment [51, 52], financial indicators [45].

Analyzing the choice of methods for the study of these types of security, we note that there is a very wide list of them. At the same time, multivariate analysis is mostly used for investigation an interaction between different parameters [53]. So, principal component analysis is broadly used in construction of integral indices for assessment of economic and social phenomena [54]. An important step for building the set of indicators is a test of its internal consistency. That is why the choice of methods of multivariate analysis will allow constructing the most complete integral characteristic of the studied types of security.

\section{Research methodology}

Taking into account some previous research in the field of environmental, economic and energy security, we have assumed that their evaluation should include a wide range of indicators. The most comprehensive statistical database for different countries is presented on the World Bank official web-site. Using such statistical data set of indicators characterizing environmental security is defined as follow:

Env1 -agricultural land,\% of land area;
Env2 - $\mathrm{CO} 2$ emissions grows, annual \%;

Env3 - forest area, \% of land area;

Env4 - $\mathrm{CO} 2$ emissions, metric tons per capita;

Env5- methane emissions, \% change from 1990;

Env6 - nitrous oxide emissions, \% change from 1990;

Env7 - population density, people per sq. $\mathrm{km}$ of land area;

Env8 - fertilizer consumption, kilograms per hectare of arable land;

Env9 - total fisheries production growth, annual \%.

To describe energy security the following indicators were selected:

Eng1- $\mathrm{CO} 2$ emissions from electricity and heat production, $\%$ of fuel combustion;

Eng2 - $\mathrm{CO} 2$ intensity, $\mathrm{kg}$ per $\mathrm{kg}$ of oil equivalent energy use;

Eng3 - electricity production from oil, gas and coal sources, $\%$ of total;

Eng4 -energy imports, net \% of energy use;

Eng 5 - oil rents (\% of GDP);

Eng6 - alternative and nuclear energy, \% of total energy use;

Eng7 - combustible renewables and waste, \% of total energy;

Eng8 - energy use ( $\mathrm{kg}$ of oil equivalent) per $\$ 1,000$ GDP (constant 2011 PPP);

Eng9 - fossil fuel energy consumption, \% of total.

Economic security indicators include the follows ones:

Econ1 - central government debt, total \% of GDP;

Econ2-GDP growth, annual \%;

Econ3 - GDP per capita, PPP constant 2011 international \$;

Econ 4 - gross fixed capital formation, $\%$ of GDP;

Econ5 - income share held by lowest $20 \%$;

Econ6 - industry (including construction) value added, annual $\%$ growth;

Econ7 -research and development expenditure, \% of GDP;

Econ8 - unemployment, \% of total labor force;

Econ 9 - current account balance, \% of GDP.

The quality of the multivariate analysis depends largely on the sample size of the study. That is why longitudinal data were used to compare the results for countries with similar development conditions. Based on this goal, Eastern European countries were selected for the study, namely Ukraine, Moldova, Poland, Romania, Hungary and Slovak Republic. Study period includes 2000-2016 that allows estimating a general trend of environmental, energy and economic security across selected countries. Considering the significant differences in the values of the selected statistics before their study, their normalization was carried out using the Min-Max method.

The next important step in the study was to test the internal consistency of the selected characteristics of the phenomena under study. The Cronbach's alpha coefficient calculation for the normalized total sample of 27 indicators showed that its value is 0.8516 , which allows going to the next stage of the study.

Taking into account the existing limitations and recommendations on the ratio of the number of variables 
and the number of observations, it is advisable to carry out multivariate analysis separately for each type of security. Stata software was used to perform the empirical calculations. The evaluation was performed simultaneously using factor analysis and principal component method.

\section{Results and discussion}

Comparison of the results showed that factor analysis allowed obtaining better results in terms of their adequacy. Table 1 demonstrates eigenvalues, individual and cumulative proportions of variance explained by each factors of environmental security indicators.

Table 1. Factor analysis parameters of environmental security estimation.

\begin{tabular}{|l|c|c|c|c|}
\hline Factor & Eigenvalue & Difference & Proportion & Cumulative \\
\hline Factor1 & 3.98073 & 2.26255 & 0.6059 & 0.6059 \\
\hline Factor2 & 1.71818 & 1.01425 & 0.2615 & 0.8674 \\
\hline Factor3 & 0.70393 & 0.40023 & 0.1071 & 0.9746 \\
\hline Factor4 & 0.30370 & 0.20293 & 0.0462 & 1.0208 \\
\hline Factor5 & 0.10077 & 0.09440 & 0.0153 & 1.0361 \\
\hline Factor6 & 0.00636 & 0.04698 & 0.0010 & 1.0371 \\
\hline Factor7 & -0.04061 & 0.02492 & -0.0062 & 1.0309 \\
\hline Factor8 & -0.06554 & 0.07203 & -0.0100 & 1.0209 \\
\hline Factor9 & -0.13756 & & -0.0209 & 1.0000 \\
\hline
\end{tabular}

Analyzing the obtained results, we note that the first two factors explain more than $80 \%$ of the variation of the selected characteristics. Thus, it is advisable to characterize environmental security precisely by these factors, the structure of which is formed by the following indicators (see Table 2). The first factor is largely determined by the dynamics of such environmental security indicators as Env1, Env3, Env4, Env8. Taking into account direct and indirect indicators signs this dimension might be named as source quality and availability. The dominant components of second factor are Env5 and Env7. Thus, it characterizes mostly environmental changes. Other selected indicators also have some influence on the formed factors but their scale is not so significant.

The final step of the multivariate analysis of environmental security is its level estimation across selected countries (see Fig. 1).
Table 2. Factor loadings for environmental security indicators.

\begin{tabular}{|c|c|c|c|c|}
\hline Variable & Factor1 & Factor2 & Factor3 & Uniqueness \\
\hline env1 & 0.9050 & -0.0797 & 0.3899 & 0.0142 \\
\hline env2 & 0.0488 & 0.2113 & -0.3892 & 0.7565 \\
\hline env3 & 0.8524 & 0.0264 & 0.1779 & 0.0303 \\
\hline env4 & -0.8584 & -0.2880 & -0.0511 & 0.0734 \\
\hline env5 & 0.5916 & 0.6333 & -0.1776 & 0.2060 \\
\hline env6 & -0.7533 & 0.3817 & 0.0073 & 0.1144 \\
\hline env7 & -0.1759 & 0.9286 & 0.0644 & 0.0967 \\
\hline env8 & -0.8347 & 0.2483 & 0.1835 & 0.1749 \\
\hline env9 & 0.2250 & 0.3359 & 0.2131 & 0.7200 \\
\hline
\end{tabular}

The results show that during the study period, a weak growing trend of environmental safety was observed in all countries. However, the absolute level of the estimated factors is significantly different for the countries studied. It can also be noted that Poland and the Slovak Republic demonstrate higher values characteristics of sources quality and availability comparing to environmental changes, while other countries have opposite trend.

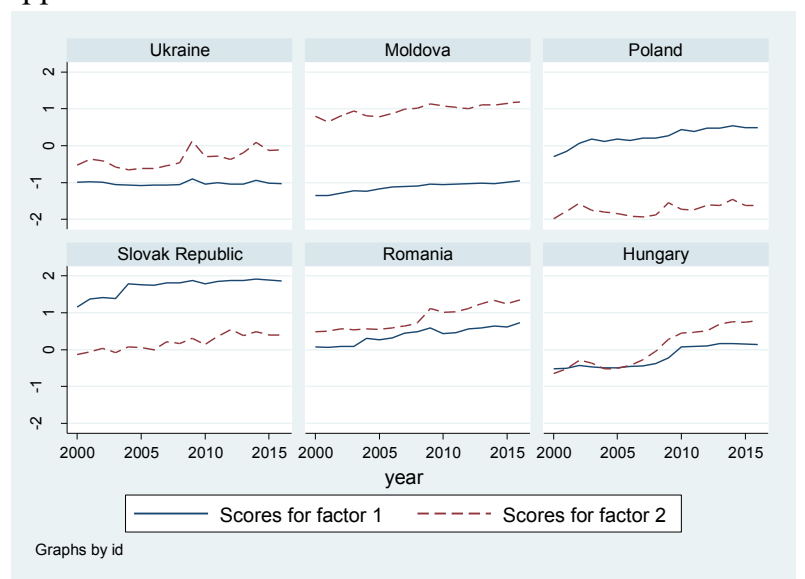

Fig. 1. Environmental security factors.

Similar methodology was applied to the estimation of energy security. This case shows that the most significant are first three factors (see Fig. 2).

Analyzing a structure of defined factors (see Table 3) it should be defined that the first one is mostly formed by such indicators as Eng1, Eng3, Eng6, Eng9. So it can be named as energy production structure. The second factor is formed by Eng2 and Eng4 indicators and describes 
energy dependence. The third one factor includes energy effectiveness in terms of total energy use reducing and role of renewable energy (Eng7 and Eng8).

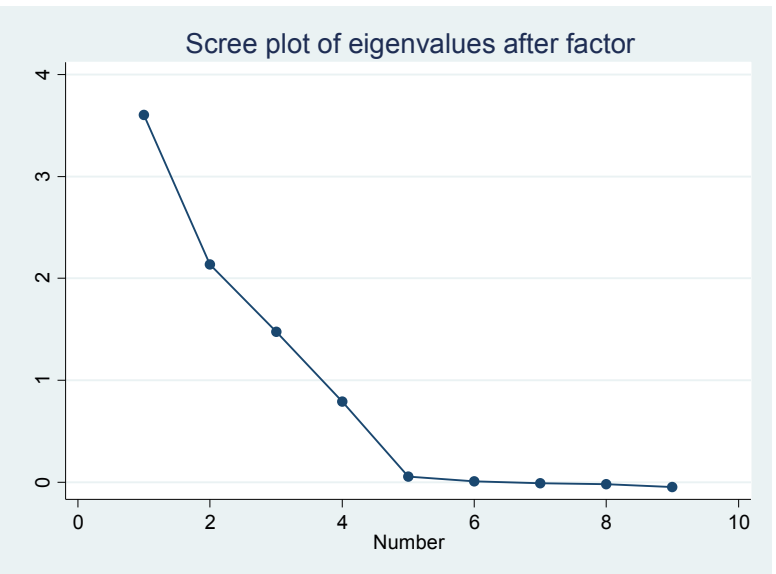

Fig. 2. Factor analysis eigenvalues for energy security.

Table 3. Factor loadings for energy security indicators.

\begin{tabular}{|c|c|c|c|c|}
\hline Variable & Factor1 & Factor2 & Factor3 & Uniqueness \\
\hline eng1 & 0.7991 & -0.0786 & -0.1804 & 0.2812 \\
\hline eng2 & 0.4978 & -0.6748 & -0.2350 & 0.0392 \\
\hline eng3 & 0.9084 & 0.3681 & 0.1626 & 0.0095 \\
\hline eng4 & -0.3062 & 0.8980 & 0.2158 & 0.0367 \\
\hline eng5 & -0.0292 & 0.5531 & 0.2830 & 0.1954 \\
\hline eng6 & 0.9355 & 0.2110 & 0.2137 & 0.0051 \\
\hline eng7 & 0.1358 & -0.4903 & 0.7462 & 0.1019 \\
\hline eng8 & -0.0435 & 0.2861 & -0.7812 & 0.2471 \\
\hline eng9 & 0.9504 & 0.2495 & -0.1552 & 0.0051 \\
\hline
\end{tabular}

The last one step of energy security estimation is presented by Figure 3. Comparing the energy security of the countries studied, we note that the structure of energy production and consumption plays the largest role for Ukraine and the Slovak Republic. A high level of energy dependency is the most important characteristic of Moldova's energy security. For Poland and Romania, energy production and consumption efficiency occupy a dominant place in energy security that is a positive feature.

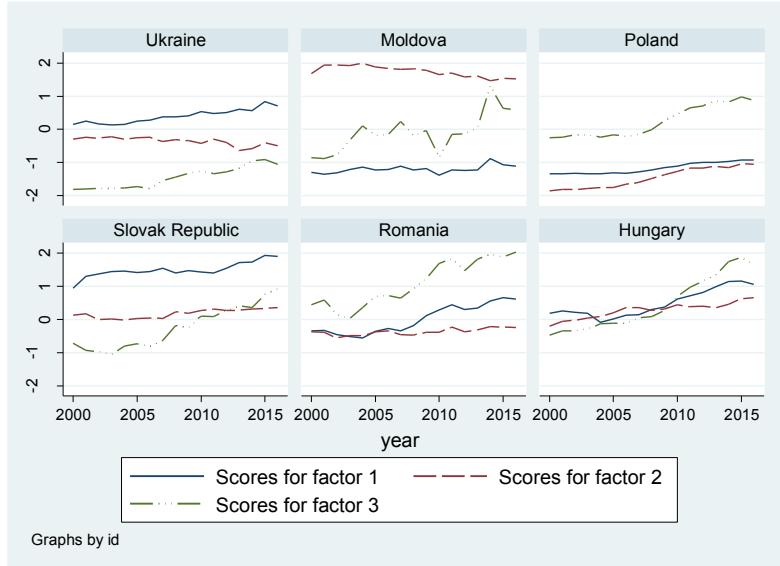

Fig. 3. Energy security factors.

The results of factor analysis of economic security are presented in Table 4.

Table 4. Factor loadings for economic security indicators.

\begin{tabular}{|c|c|c|c|c|}
\hline Variable & Factor1 & Factor2 & Factor3 & Uniqueness \\
\hline econ1 & 0.6241 & -0.2626 & 0.1855 & 0.4858 \\
\hline econ2 & 0.5421 & 0.6495 & 0.1994 & 0.2336 \\
\hline econ3 & -0.3445 & 0.3589 & -0.5404 & 0.4568 \\
\hline econ4 & 0.5458 & 0.0626 & -0.4715 & 0.4306 \\
\hline econ5 & -0.3545 & -0.0733 & 0.2430 & 0.6196 \\
\hline econ6 & 0.4107 & 0.7272 & 0.1575 & 0.2721 \\
\hline econ7 & -0.6770 & 0.2974 & -0.0792 & 0.2928 \\
\hline econ8 & 0.2336 & -0.2408 & 0.0625 & 0.6995 \\
\hline econ9 & -0.6254 & 0.2651 & 0.3189 & 0.3994 \\
\hline
\end{tabular}

This type of security is formed by two first factors providing $82 \%$ of total variance. Factor 1 includes mostly Econ1, Econ4, Econ7 and Econ9. This dimension characterizes national economy potential and independence. For the second factor dominant indicators are Econ2 and Econ6. Its might be named as real economy development.

Analyzing the identified levels in economic security in the context of the studied countries (see Fig. 4), we note that, unlike the previous results, in this case it is difficult to identify clear trends in the prevalence of different factors or the presence of individual profiles of countries. 
Attention should be paid to the high volatility of economic security components throughout the study period, which is the case for most of the countries studied. Moreover, the sharpest fluctuations were in the crisis period 2007-2009 and in the post-crisis period 2010-2012. The only exception is Poland. Its economic security was characterized by the lowest level of fluctuation during the analysis period.

However, it should be noted that the overall long-term downward trend in economic security is observed in all the countries studied. This indicates the necessity of directing efforts in the "environmental-energy-economic security" triangle precisely on this type of security.

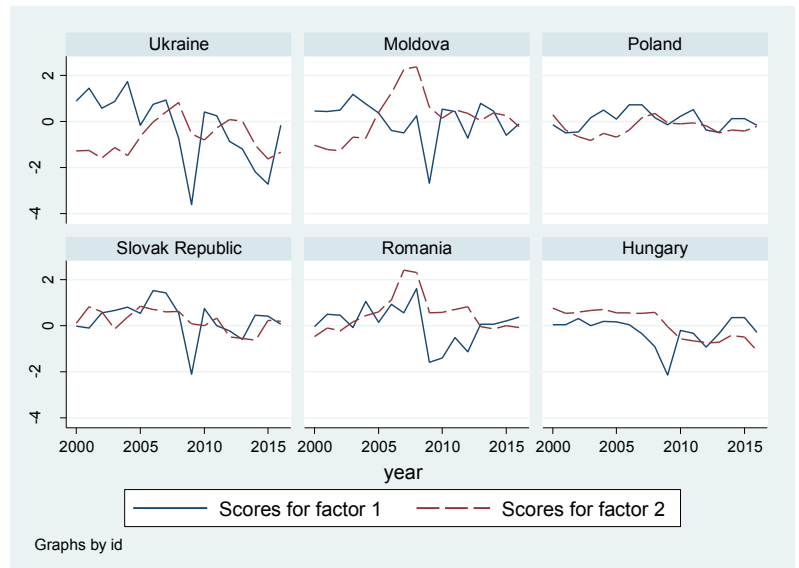

Fig. 4. Economic security factors.

Using the results of factor analysis, the integral levels of environmental, energy and economic security were estimated, combining the factors identified in the previous stages, taking into account the factor loadings of the selected indicators.

In order to determine the prospects for the simultaneous regulation of environmental, energy and economic security, the interaction between them should be considered (see Fig. 5).

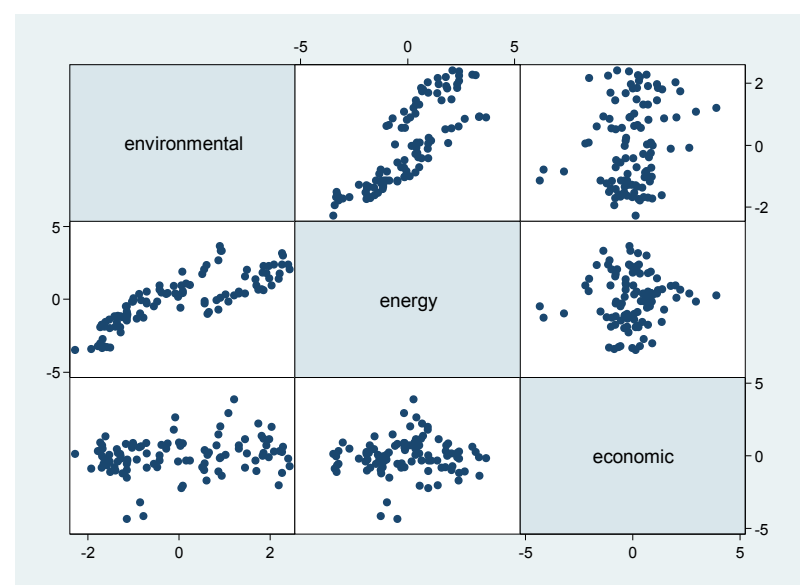

Fig. 5. Interaction of security types.

It should be noted that the closest connection is characteristic of environmental and energy security, which change in a single vector, which indicates that there are prospects for their simultaneous growth.
Environmental and economic security types have some potential for providing synergistic regulatory effects. At the same time, the least interaction is characteristic of energy and economic security, which is related to the significant role of energy dependence and commodity economy of the countries studied.

\section{Conclusions}

The spread of globalization and integration trends necessitates the application of integrated approaches to the study of all phenomena. The concept of sustainable development has proven the importance of synergies between economic, environmental and social components. At the same time, environmental, economic and energy security are important complementary characteristics at national security level. The multivariate analysis showed that the most important factors for environmental safety are the quality and availability of resources, as well as environmental changes. Energy security is most fully characterized as the ratio of three components - the structure of energy production, energy dependence and energy efficiency. The potential of the national economy and the development of the real sector should be considered as factors of economic security.

Assessing the level of interaction between environmental, economic and energy security shows that there are prospects for the development of integrated regulatory mechanisms in the field of national security. The greatest potential for synergy is environmental and energy security, the lowest - energy and economic. Thus, the prospects for further research are to find the most effective regulatory tools for the simultaneous growth of the types of safety under study. Environmental taxation has a great potential in this area.

\section{Acknowledgments}

The survey was supported by the Ministry of Education and Science of Ukraine and performed the results of the projects 0119U100759; $0118 \mathrm{U} 003569$ and $0120 \mathrm{U} 102001$.

\section{References}

1. H. Dkhili, MMI 3, 333-244 (2018). http://doi.org/10.21272/mmi.2018.3-30

2. L.L. Hrytsenko, T.Y. Krasulya, APE 126(12), 85-90 (2011).

3. V. Koziuk, Y. Hayda, O. Dluhopolskyi, Y. Klapkiv, E\&S 12(4), 278-298 (2019). doi:10.14254/2071789X.2019/12-4/17

4. T. Vasilyeva, O. Kuzmenko, V. Bozhenko, O. Kolotilina, Assessment of the dynamics of bifurcation transformations in the economy, in CEUR Workshop Proceedings, 2422, 134-146 (2019).

5. O. Chygryn, T. Pimonenko, O. Luylyov, A. Goncharova, J. Env. Man. and T. 9(7), 1443-1456 (2018). DOI: 10.14505/jemt.v9.7(31).09. 
6. Masharsky, G. Azarenkova, K. Oryekhova, S. Yavorsky, MMI arketing and Management of Innovations, $\quad 3, \quad 345-354 \quad$ (2018). http://doi.org/10.21272/mmi.2018.3-31

7. H. Shvindina, Saf., 5(3), 61 (2019). DOI: 10.3390/safety5030061

8. Grenčíková, Y. Bilan, Y. Samusevych, A. Vysochyna, Drivers and inhibitors of entrepreneurship development in central and eastern European countries, in Proceedings of the 33rd International Business Information Management Association Conference, IBIMA 2019: Education Excellence and Innovation Management through Vision 2020, 2536-2547 (2019).

9. Pomianek, BEL 2(2), 74-83 (2018). DOI: 10.21272/bel.2(2).74-83.2018.

10. Y. Bilan, S. Lyeonov, T. Vasylieva, Y. Samusevych, Online J. Model.New Eur. (27), 34-66 (2018). DOI: 10.24193/OJMNE.2018.27.02

11. Y. Bilan, T. Pimonenko, L. Starchenko, E3S Web of Conferences 159, $04037 \quad$ (2020) DOI: 10.1051/e3sconf/202015904037

12. T. Bondar, Y. Matvieieva, I. Myroshnychenko, Ec. An.-XXI 7-8(1), 40-44 (2015). http://soskin.info/userfiles/file/2015/78_1/Bondar_Matvieieva_Myroshnychenko.pdf

13. Makarenko, N. Sirkovska, BEL 1(1), 16-24 (2017). Doi: 10.21272/bel.2017.1-02

14. T. Pimonenko, Y. Bilan, J. Horák, L. Starchenko, W. Gajda, Sustainability (Switzerland), 12(4), 1679 (2020). https://doi.org/10.3390/su12041679

15. V. Sukhonos, I. Makarenko, PPM 15(1), 166-174 (2017). DOI:10.21511/ppm.15(1-1).2017.03

16. Y. Bilan, S. Lyeonov, O. Lyulyov, T. Pimonenko, Pol. J. Man. St., 19(2), 61-74 (2019). DOI: 10.17512/pjms.2019.19.2.05

17. M.P. Bhandari, Cl. Ch. Man. 149-167 (2013). DOI: 10.1007/978-3-642-31110-9_10.

18. Y. Bilan, T. Vasylieva, S. Lyeonov, I. Tiutiunyk, $\begin{array}{llll}\text { EBER 7(2), 27-43 (2019). DOI: } & \end{array}$ 10.15678/EBER.2019.070202.

19. M.P. Bhandari, SEC 2(3), 6-25. (2018). DOI: 10.21272/sec.3(2).6-25.2018.

20. Y. Bilan, P. Rubanov, T. Vasylieva, S. Lyeonov, Pol. J. Man. St. 9(1), 70-93 (2019). DOI: 10.17512/pjms.2019.19.1.06.

21. Y. Bilan, T. Vasilyeva, O. Kryklii, G. Shilimbetova, Cr. St. 12(1), 75-101 (2019). DOI: https://doi.org/10.3846/cs.2019.7453.

22. Y. Bilan, O. Kuzmenko, A. Boiko Research on the impact of industry 4.0 on entrepreneurship in various countries worldwide, in Proceedings of the 33rd International Business Information Management Association Conference, IBIMA 2019: Education Excellence and Innovation Management through Vision 2020, 2373-2384 (2019). https://ibima.org/accepted-paper/research-on-the- impact-of-industry-4-0-on-entrepreneurship-invarious-countries-worldwide/

23. J. Cebula, O. Chygryn, S.V. Chayen, T. Pimonenko, IJETM 21(5-6), 421-438 (2018). DOI: 10.1504/IJETM.2018.100592

24. O. Lyulyov, T. Vasylieva, ESD 1, 878-887 (2019). DOI: $10.14254 / 1800-5845 / 2018.14-1.12$

25. Y. Yevdokimov, O. Chygryn, T. Pimonenko, O. Lyulyov, Inn. Mark. 14(2), 7-15 (2018). DOI: 10.21511/im.14(2).2018.01.

26. Kendiukhov, M. Tvaronavičienè, MMI 3, 33-42 (2017). DOI: http://doi.org/10.21272/mmi.2017.3-03

27. Y. Bilan, A.G. Raišienė, T. Vasilyeva, O. Lyulyov, T. Pimonenko, PPA 18(2), 241-255 (2019). DOI: 10.13165/VPA-19-18-2-05

28. Boiko, I. Samusevych, FMIR 1(1), $72-79$ (2017). http://doi.org/10.21272/fmir.1(1).72-79.2017.

29. R. Ch, A. Semenog, FMIR 1(2), 39-49 (2017). DOI: 10.21272/fmir.1(2).39-49.2017.

30. I.V. Tiutiunyk, IJED 33(3), 11-18 (2018). https://essuir.sumdu.edu.ua/bitstreamdownload/123456789/74030/1/P2-Determination.pdf

31. Y. Matvieieva, I. Myroshnychenko, L. Valenkevych, JEMT 10(8), 1874-1899 (2019). DOI: https://doi.org/10.14505//jemt.10.8(40).17

32. S.N. Singh, SEC 2(2), 41-48 (2018). DOI: 10.21272/sec.2(2).41-48.2018

33. D.T.Am. Marcel, FMIR 3(2), 69-78 (2019). DOI: http://doi.org/10.21272/fmir.3(2).69-78.2019

34. M.P. Bhandari, Green Web-II: Standards and Perspectives from the IUCN Program and Policy Development in Environment Conservation Domain: A Comparative Study of India, Pakistan, Nepal, and Bangladesh, 1-330 (2018).

35. H. Dave, BEL 1(2), 78-87 (2017). Doi: 10.21272/bel.1(2).78-88.2017.

36. H. Dave, BEL 1(3), 45-63 (2017). DOI: 10.21272/bel.1(3).45-63.2017

37. T. Shevchenko, I. Koblianska, L. Saher, JEMT 7(3), 361-369 (2016). DOI: 10.14505/jemt.v7.3(15).01.

38. T. Vasilyeva, S. Bilan, K. Bagmet, R. Seliga, E\&S 13(1), 271-294 (2020). DOI: 10.14254/2071789X.2020/13-1/17.

39. L. Rui, L. Sineviciene, L. Melnyk, (...), O. Karintseva, O. Lyulyov, PPM 17(3), 233-241 (2019). DOI: $10.21511 / \mathrm{ppm} .17(3) .2019 .19$.

40. L.F. Sokolenko, I.V. Tiutiunyk, D.V. Leus, IJED 32(3), 27-35 (2017). https://www.academia.edu/40570162/Ecological_and _Economic_Security_Assessment_in_the_System_of _Regional_Environmental_Management_A_Case_St udy_of_Ukraine

41. Aliyas, E. Ismail, M. Alhadeedy, SEC 2(2), 75-80 (2018). DOI:10.21272/sec.2(2).75-80.2018.

42. Bilan, Y., Lyeonov, S., Stoyanets, N., Vysochyna, A. The impact of environmental determinants of 
sustainable agriculture on country food security. IJETM 21(5-6), 289-305 (2018). DOI: 10.1504/IJETM.2018.100580

43. O. Lyulyov, T. Pimonenko, N. Stoyanets, N. Letunovska, Res. WE 10(4), 97-105 (2019). DOI: 10.5430/rwe.v10n4p97.

44. S. Lyeonov, T. Pimonenko, Y. Bilan, D. Streimikiene, G. Mentel, Energies 12(20), 3891 (2019). DOI: 10.3390/en12203891

45. T. A. Vasylyeva, S. A. Pryymenko, APE 160(1), $252-260$ https://www.researchgate.net/publication/297884624 _Environmental_economic_assessment_of_energy_r esources_in_the_context_of_ukraine's_energy_securi ty

46. Y. Bilan, T. Vasilyeva, S. Lyeonov, K. Bagmet, Bus.: Th\&Pr 20, 103-115 (2019). DOI: https://doi.org/10.3846/btp.2019.10

47. G. Mentel, T. Vasilyeva, Y. Samusevych, S. Pryymenko, IJETM 21(5-6), 354-372 (2018). DOI: 10.1504/IJETM.2018.100583

48. Y. Bilan, T. Vasilyeva, O. Lyulyov, T. Pimonenko, IJBS 20(2), 433-450 (2019). http://www.ijbs.unimas.my/images/repository/pdf/V ol20-no2-paper1.pdf

49. H. Zhang, E. Xu, Sc. Rep., 7, 811, (2017). DOI: 10.1038/s41598-017-00899-x

50. Stavytskyy, G. Kharlamova, V. Giedraitis, V. Šumskis, JIS 11(3), 217-238 (2018). doi:10.14254/2071-8330.2018/11-3/18.

51. M. Bublyk, V. Koval, O. Redkva, MMI (4), 229-240 (2018). https://doi.org/10.21272/mmi.2017.4-20

52. O.V. Kozmenko, O.M. Pakhnenko, APE 118(4), 217-223 (2011).

53. Y. Bilan, M. Brychko, A. Buriak, T. Vasilyeva, ZREFR 37(1), 113-138 (2019). DOI: 10.18045/zbefri.2019.1.113

54. T. Vasilyeva, S. Lyeonov, I. Adamičková, K. Bagmet, E\&S 11(2), 248-262 (2018). doi:10.14254/2071-789X.2018/11-2/17 